4. Красноярская региональная организация общественной организации «Союз композиторов России» : [обзор фонда Государственного архива Красноярского края]// Архивы Красноярского края : офиц. сайт. Красноярск, 2011-. - URL: http://красноярские-архивы.pф/gosudarstvennyi-arkh/nauchno-spravochnyiapparat/obzory-fondov/701 (дата обращения: 11.03.2019).

5. Бачинская, Н. М. Русское народное музыкальное творчество : хрестоматия / Н. М. Бачинская, Т. В. Попова. - Москва : Музыка, 1974. - 302 с.

6. Заозёрских, А. В. Мемориальные жанры в искусстве (на примере творчества Романа Леденева)/ А. В. Заозёрских, М. М. Чмхачёва // Культура и искусство: поиски и открытия : сб. науч. ст. - Кемерово : Кемеров. гос. инст. культуры, 2017. - С. 39-44.

Alyona V. Zaozyorskikh

Dmitri Hvorostovsky Siberian State Institute of Arts (Krasnoyarsk, Russia) alyona61193@mail.ru

Scientific Chief - Maria M. Chikhachyova, Ph. D. in Art Criticism, Associate Professor Dmitri Hvorostovsky Siberian State Institute of Arts (Krasnoyarsk, Russia) mgokhfeld@yandex.ru

\title{
MUSIC IN MEMORIAM BY MELODISTS FROM KRASNOYARSK REGIONAL PUBLIC ORGANIZATION OF THE RUSSIAN PUBLIC ORGANIZATION "UNION OF COMPOSERS OF RUSSIA"
}

The reported study was funded by Krasnoyarsk Krai Scientific and Research Activities Support Fund

\begin{abstract}
The paper discloses specifics of music in memoriam using modern Siberian classic melodists' works. The author notes sustainable interest of Siberian composers to making "musical monuments", artistic opuses in memoriam that have a task to show respect for another passed genius as a melodist's creative idea. The author of the article reveals some peculiarities of composing techniques, ways of combination of musical expressive means noticed in texts of musical opuses dedicated to the memory of passed artists on the examples of the next two musical pieces written by members of Krasnoyarsk Regional Public Organization of the Russian Public Organization "Union of Composers of Russia" (Krasnoyarsk, Russia) - "Quartet No. I" (op. 8) by Igor Fleisher (1949), dedicated to the memory of Soviet composer Alfred Schnittke (1934-1998), and "Fantasy in memory of Andrei Petrov" by Vladimir Karpenko (1958).

Keywords: music "in memoriam", musical opuses "in memoriam", a narratee for musical composition "in memoriam", memory in art, modern Siberian composers, composers from Krasnoyarsk Regional Public Organization of the Russian Public Organization "Union of Composers of Russia", Igor Fleisher (composer), Vladimir Karpenko (composer), Alfred Schnittke (composer), Andrei Petrov (composer).
\end{abstract}

УДК 82.312-1Толстой+Пастернак]:[782.1:7.071.1Лубченко]

DOI: 10.32340/2414-9101-2019-4-34-39

Д. В. Калинина

Сибирский государственный институт искусств им. Дмитрия Хворостовского

(Красноярск, Россия)

deresel@yandex.ru

\section{«АННА КАРЕНИНА» Л. Н. ТОЛСТОГО И «ДОКТОР ЖИВАГО» Б. Л. ПАСТЕРНАКА - ЛИТЕРАТУРНЫЕ ИСТОЧНИКИ МУЗЫКАЛЬНЫХ ПРОИЗВЕДЕНИЙ А. В. ЛУБЧЕНКО}

Исследование выполнено при поддержке Красноярского краевого фонда поддержки научной и научно-технической деятельности.

Аннотация. Охарактеризован исторический и социально-политический контекст создания признанных шедевров русской и мировой литературы: романа Л. Н. Толстого «Анна Каренина» (18731877 гг.) и романа Б. Л. Пастернака «Доктор Живаго» (1945-1955 гг.), составивших литературную основу для исторической музыкальной драмы в 15 сценах «Доктор Живаго» (ор. 71; 2010 г.) и драматической поэмы для большого симфонического оркестра «Анна Каренина» (ор. 74; 2010 г.) современного российского композитора и дирижёра А. В. Лубченко (род. в 1985 г.). Автор статьи отмечает идейно-художественное созвучие, тематическую и эстетическую близость романов, разделённых более чем полувековой дистанцией, излагает некоторые факты биографии писателей, получившие художественное осмысление в литературных текстах, приводит примеры отзывов современников писа- 
телей о философских и художественных достоинствах произведений. Автор выдвигает предположения о причинах, по которым основой композиторского замысла А. В. Лубченко стали сюжетные конструкции упомянутых произведений русской классической литературы.

Ключевые слова: Л. Н. Толстой, «Анна Каренина» (роман), Б. Л. Пастернак, «Доктор Живаго» (роман), А. В. Лубченко (композитор), «Анна Каренина» (драматическая поэма для большого симфонического оркестра), «Доктор Живаго» (историческая музыкальная драма в 15 сиенах), прототипь героев, драматургия, крупные формы инструментальной оркестровой музыки.

Лев Николаевич Толстой (1828-1910) и Борис Леонидович Пастернак (1890-1960) вошли в историю как яркие и самобытные писатели, произведения которых широко известны во всём мире.

Доказательством актуальности романов является их интерпретация современным композитором Антоном Владимировичем Лубченко (р. 1985): русская музыкальная драма «Доктор Живаго» и драматическая поэма для большого симфонического оркестра «Анна Каренина». Работа над произведениями проходила параллельно и началась в 2010 году. В 2015 году они прозвучали за рубежом.

Исполнение драматической поэмы «Анна Каренина» состоялось в столице Китая. Мастерство азиатских музыкантов поразило композитора, поэтому его произведение посвящено Пекинскому симфоническому оркестру.

Премьера музыкальной драмы «Доктор Живаго» прошла в Регенсбурге (Германия) и вызвала широкий резонанс среди критиков и театральной публики. По словам композитора, в опере «Доктор Живаго» он, опираясь на образцы произведений М. П. Мусоргского («Хованщина»), П. И. Чайковского («Мазепа») и С. С. Прокофьева («Семён Котко», «Война и мир»), попытался создать новую национальную оперу путём синтеза разных традиций русской школы. Наиболее интересным композитор считает в музыке данного произведения «сознательный эклектизм» [1].

Размышляя о том, почему А. В. Лубченко выбрал именно эти сюжеты для своих музыкальных опусов, возникают вопросы: чем обусловлены интонационно-тематические связи, которые обнаруживаются при сравнении музыкальных произведений и, соответственно, есть ли что-то общее в романах «Анна Каренина» и «Доктор Живаго»? Все дальнейшие рассуждения будут посвящены поиску близких сюжетных мотивов и аналогий, возникающих при изучении литературных произведений XIX и XX веков.

Несмотря на то, что Пастернак и Толстой имели большую разницу в возрасте, их знакомство всетаки состоялось. Борис Пастернак общался со Львом Толстым благодаря своему отцу Леониду Осиповичу, который был художником. Помимо Льва Толстого, Борис Леонидович в детстве видел у себя дома многих известных людей: художников Валентина Серова, Исаака Левитана, Михаила Врубеля, Василия Поленова, Константина Коровина, композиторов Александра Скрябина, Сергея Рахманинова и многих других.

Немаловажно, что отец писателя, Леонид Пастернак, был автором иллюстраций к романам «Война и мир» и «Воскресение». Л. Н. Толстой глубоко уважал эти работы, отмечая, что все его персонажи, даже второстепенные, отличаются ясной психологической и социальной характеристикой. Рассматривая полотна, написанные Л. Пастернаком, можно ясно представить себе определённую сцену романа. Семья Пастернаков часто навещала Толстых, как в Москве, так и в Ясной Поляне, в результате чего появилась серия портретов, созданная Леонидом Пастернаком. Именно эти работы кисти русского художника исследователи называют «зеркалом» Льва Николаевича.

Возможно, именно общение с Толстым сыграло важную роль в становлении творческой личности Бориса Пастернака.

По словам современников, Пастернак считал Толстого «несравненным гением, более великим, чем Диккенс и Достоевский, - писателем ранга Шекспира, Гёте и Пушкина» [2, с. 524]. Борис Леонидович ценил величественную конкретность Льва Толстого, его «железную причинность и логику резко обрисованных характеров» [2, с. 482]. Приведём ещё одну показательную цитату Бориса Пастернака: «И все же главное и непомернейшее в Толстом то, что больше проповеди добра и шире его бессмертного художнического своеобразия (а, может быть, и составляет именно истинное его существо), новый род одухотворения в восприятии мира и жизнедеятельности, то новое, что принёс Толстой в мир и чем шагнул вперёд в истории христианства, стало и по сей день осталось основою моего существования, всей манеры моей жить и видеть» [3]. 
Б. Л. Пастернак всегда тяготел к правдивому изображению действительности, искусство для него, в первую очередь, было отражением нравственной жизни людей. И здесь опыт Л. Н. Толстого сыграл для него главную роль.

Особое место в творческом наследии Л. Н. Толстого занимает роман «Анна Каренина». Работу над произведением писатель начал на почве собственных переживаний. Если в «Войне и мире» Толстой «любил мысль народную, вследствие войны 1812 года» [4, с. 14], то в «Анне Карениной» ему была дорога «мысль семейная» [4, с. 14]. Лев Николаевич называл «Анну Каренину» «романом широким, свободным, в который без напряжения входило» все то, что было «понято с новой, необычной и полезной людям стороны» [5, с. 6].

В своё время «Анна Каренина» подверглась острой критике. Так, например, историк русской литературы А. М. Скабичевский заподозрил Л. Н. Толстого в сговоре с издателем «Русского вестника», предполагая, что роман печатался лишь для получения гонорара и для того, чтобы страницы журнала не остались пустыми. А. М. Скабичевский отмечал, что все произведение пропитано «идиллическим запахом детских пелёнок», но позднее изменил своё мнение и даже хотел предложить Толстому «блистательную идею: никогда не кончать роман» [6, с. 111]. И. С. Тургенев писал об «Анне Карениной»: «Гораздо большее разочарование <... принёс нам роман Л. Н. Толстого. С его талантом забрести в это великосветское болото и топать, и толкаться там на месте - и относиться ко всей этой дребедени не с юмором - а, напротив, с пафосом, серьёзно - что за чепуха! Москва загубила его - не его первого, не его последнего» [7]. Негативные отзывы об «Анне Карениной» были высказаны так же писателем А. В. Станкевичем и учёным С. А. Рачинским.

Вершиной творчества Б. Л. Пастернака является роман «Доктор Живаго», в котором писатель подводит итог своих размышлений о нравственности и предназначении человека, о силе настоящего чувства, о революции.

В 1958 году Б. Л. Пастернак был удостоен Нобелевской премии «за выдающиеся заслуги в современной лирической поэзии и в области великой русской прозы», но советские партийные органы признали «Доктора Живаго» идеологически вредным, клеветническим произведением. Пастернак был исключён из членов Союза писателей. Его также заставили отказаться от награды и настойчиво требовали покинуть родные края, на что Борис Леонидович твёрдо возразил: «Оставить родину для меня равносильно смерти... Я связан с Россией рождением, жизнью и работой» [8]. В столь тяжёлое время с Пастернаком перестали общаться близкие друзья. Жесточайшая критика, оскорбления и обвинения в его адрес постоянно звучали в средствах массовой информации.

Как ни странно, но «Доктор Живаго» Б. Л. Пастернака во многом схож с романом «Анна Каренина» Л. Н. Толстого. В первую очередь, отметим, что в обоих произведениях обнаруживаются «зашифрованные портреты» самих авторов. В «Анне Карениной» Л. Н. Толстой является прототипом Константина Левина с его искренностью, добрым отношением к крестьянам, обращением к вере. Размышляя об «Анны Карениной», Д. Н. Овсянико-Куликовский замечает: «...Левин блистательно заканчивает эту художественную автобиографию, эту историю внутреннего развития Толстого, историю его стремлений выйти из тисков великосветской жизни и создать себе независимую от неё душевную жизнь на основах широких общечеловеческих идеалов» [9, с. 185]. Фамилия «Левин» была избрана Толстым неспроста - она произошла от имени писателя.

Исследователи творчества Б. Пастернака Дмитрий Лихачёв и Дмитрий Быков считают, что сюжетом романа «Доктор Живаго» стала собственная жизнь писателя, но не реально им прожитая - это духовная автобиография Пастернака, написанная им с предельной откровенностью [10, с. 356], [11, c. 112].

Юрий Живаго, как и Борис Пастернак, является хранителем христианских ценностей, главными из которых, по мнению самого автора, были жертвенность и щедрость, а также любовь к земле. Приведём строки из романа: «Какое счастье работать на себя и семью с зари до зари, сооружать кров, возделывать землю в заботе о пропитании, создавать свой мир, подобно Робинзону, подражая Творцу в сотворении вселенной, вслед за родной матерью производя себя вновь и вновь на свет!» [12, с. 272]. Пастернак отмечал, что соединил в образе Юрия Живаго черты Александра Блока, Владимира Маяковского, Сергея Есенина и самого себя. Главный герой выражает мысли, взгляды, мироощущение и сомнения Бориса Пастернака, а также пишет стихи.

Фамилия главного героя романа - Живаго - этимологически связана со словом живой. Писатель комментировал свой выбор так: «Фамилия моего героя? Это история непростая. Ещё в детстве я был поражён, взволнован строками из молитвы: “Ты есть воистину Христос, сын Бога живаго”» [13]. 
Продолжая сравнение литературных произведений, стоит отметить, что авторы особое значение придают семантике снов главных действующих лиц - Анны и Вронского, Лары и Живаго. В романе Толстого Анна и Вронский видят один и тот же сон (про взъерошенного мужичка), который для Карениной становится предзнаменованием её гибели Сновидения в романе «Доктор Живаго» также предшествуют важным событиям в жизни героя.

Известно, что все ключевые сцены романа «Анна Каренина» связаны с железной дорогой. Главная героиня постоянно путешествует из Петербурга в Москву. Прибыв в Москву, в гости к брату, Анна знакомится с Вронским и становится свидетелем смерти вокзального рабочего. Именно несчастье на железной дороге является предвестником рокового исхода жизни Карениной, так как на протяжении романа она постоянно вспоминает этот случай. Жизнь главной героини трагически обрывается на железной дороге. В финале романа Стива, брат Анны, на вокзале встречает Вронского, который отправляется на войну в Сербию.

В романе «Анне Каренина» железная дорога и паровоз - символ цивилизации, оказывающей негативное воздействие на традиционный уклад русской жизни. Смерть ждёт не только Анну, «бабьей душе России» (Н. Бердяев) тоже угрожает гибель под напором цивилизации.

Анализируя роман «Доктор Живаго», критик Н. Иванова отмечает, что скрепляющим элементом композиции произведения так же, как и в «Анне Карениной», является мотив железной дороги [13]. В начале романа погибает отец Юрия, выбросившись на ходу из курьерского поезда. В бронированном вагоне происходит важнейшая для развития сюжета встреча Живаго и Стрельникова. Рядом с железной дорогой находится будка, в которой живёт Марфа - бывшая прислуга Лары, именно у нее находилась Таня - дочь Юрия и Лары. Показательно, что и смерть главного героя Юрия Андреевича Живаго происходит на трамвайной остановке.

Сравнивая романы Л. Толстого и Б. Пастернака, обратимся также к прототипам и характеристикам женских персонажей произведений. Одним из прообразов главной героини «Анны Карениной» исследователи называют княгиню Александру Алексеевну Оболенскую (урожденную Дьякову) - основательницу женской гимназии в Петербурге [14, с. 12]. В 1852 г. Л. Н. Толстой сделал ей предложение, но получил отказ. Отметим созвучие фамилий Оболенская и Облонская (девичья фамилия Карениной).

Главная героиня «Доктора Живаго» сочетает в себе черты по меньшей мере двух женщин, сыгравших важную роль в жизни Б. Пастернака: его второй жены Зинаиды Нейгауз и его возлюбленной Ольги Ивинской. Пастернак сравнивал судьбу Ларисы с загадочной судьбой России, которая во время войны потерялась в бескрайних просторах невиданной дали. Лариса (с греч.) - «чайка», Гишар (с франц.) - «решётка». Таким образом, имя героини отождествляется с личностью одухотворённой, свободной, но попавшей под лавину революционных перемен и гибнущей в тюрьме.

В Анне и в Ларе органично сочетаются стихийное, природное начало и тонкое чувство культуры. Обе женщины вызывают восхищения мужчин и осознают это.

Героини выходят замуж отнюдь не по любви. При этом и Каренин, и Антипов-Стрельников во главу угла ставят служение Родине: Алексей Каренин, являясь высокопоставленным чиновником, все силы направляет на осуществление служебных интересов, Павел Антипов во имя борьбы за революцию бросает жену и дочь и уходит добровольцем на фронт.

В итоге обе женщины оказываются между двумя мужчинами-антиподами - мужем и любовником, и запретная любовь, дарованная Ларе и Анне как истинная радость, становится смыслом их жизни.

Анна и Лара - матери, беззаветно любящие своих детей. Ожидая скорый арест, Лара постоянно думает о предстоящей разлуке и дальнейшей судьбе дочери Катеньки. Для Анны расставание с сыном Серёжей после распада брака становится невыносимой болью, тревожащей её до конца дней. У обеих женщин рождаются внебрачные дочери.

Показательны и взаимосвязаны финалы романов. После смерти главных героев, Анны Карениной и Юрия Живаго, их возлюбленные не могут пережить боль утрат - Алексей Вронский в поисках смерти уезжает добровольцем воевать с турками в Сербии, Лара пропадает без вести.

В драматической поэме «Анна Каренина» композитору Антону Лубченко было важно отразить трагедию героини, запечатлеть именно тот момент, когда Анна осталась наедине со своим горем и осознала безвыходность сложившейся ситуации. В произведении присутствуют две образноинтонационные сферы, первая из которых связана с главной героиней, её мыслями, чувствами, переживаниями (личностное), а вторая представлена темами внешних злых сил, разрушающих внутренний мир Анны и предвещающих её неотвратимую гибель (внеличностное). 
Роман Б. Пастернака привлёк А. Лубченко возможностью показать, как русский человек проносит любовь и свет надежды сквозь войны и революции, отразить конфликт между его поэтическим внутренним миром и реалиями времени. Автором либретто выступил сам композитор, получив одобрение наследников Б. Пастернака.

Как отмечает Антон Владимирович, работа над оперой проходила с перерывами в течение шести лет. Либретто и музыка дорабатывались несколько раз. Изначально русская музыкальная драма готовилась к постановке в одном из московских театров, но большую заинтересованность проявил Регенсбургский театр. А. В. Лубченко отмечает: «Здесь есть некоторая почти мистическая закономерность - ведь и роман Пастернака был сначала издан не на Родине писателя» [15].

Главная сюжетная линия музыкально-сценического произведения связана с взаимоотношениями Юрия Живаго и Лары. Композитор поясняет: «Первично для меня было важно показать линию любви Лары и Живаго, ведь именно они проходят через войны, революции и другие катаклизмы. Живаго в начале оперы и в конце неё - это два разных человека, он очень сильно меняется» [1].

Немаловажно, что к творчеству Пастернака А. В. Лубченко обратился ещё раз. В 2017 году им был создан вокальный цикл для голоса и фортепиано «Свадебные и погребальные песни Юрия Живаго», посвящённый Владимиру Байкову и Якову Кацнельсону.

Несмотря на то, что романы «Анна Каренина» и «Доктор Живаго» были написаны в разное время, в разные эпохи, их многое объединяет. При этом в истории любви Анны и Вронского важен социальный контекст, а взаимоотношения Лары и Живаго развиваются на фоне исторических событий. А. В. Лубченко работал над произведениями разных жанров параллельно, создав яркие прочтения романов Л. Толстого и Б. Пастернака. Очевидно, благодаря вышеперечисленным фактам общности двух литературных творений, обнаруживается и интонационно-тематическое родство музыкальных произведений современного композитора.

\section{Список литературы}

1. Шатилова, М. На сцене Приморского театра состоялась российская премьера оперы «Доктор Живаго» // ClassicalMusicNews.Ru : [новости академической музыки]. - Москва, 2006- . - URL: https://www.classicalmusicnews.ru/reports/na-scene-primorskogo-teatra-sostoyalas-rossiiyskaya-prem-era-operydoktor-zhivago/ (дата обращения: 14.03.2019).

2. Воспоминания о Борисе Пастернаке : [сб.]/ сост., подгот. текста, коммент. Е. В. Пастернак, М. И. Фейнберг. - Москва : Слово, 1993. - 750 с.

3. Кшондзер, М. Л. Н. Толстой в творческом восприятии Бориса Пастернака // На холмах Грузии : сайт литер. альманаха. - Тбилиси, 2005-.- URL: http://kholmy-gruzii.klamurke.com/02/kschondser_tolstoi.htm (дата обращения: 16.02.2019).

4. Толстой, Л. Н. Анна Каренина : роман. - Москва : Художественная литература, 1985. - 766 с. $160 \mathrm{c}$.

5. Бабаев, Э. Г. «Анна Каренина» Л. Н. Толстого : моногр. - Москва : Художественная литература, 1978. -

6. Галаган, Г. Я. Л. Н. Толстой: художественно-этические искания : - Ленинград : Наука, 1981. - 176 с.

7. Критика о романе «Анна Каренина» Толстого: отзывы современников // Literaturus.ru. Мир русской литературы : сайт. - 2015- . - URL: http://www.literaturus.ru/2017/03/kritika-anna-karenina-tolstoj-otzyvy.html (дата обращения: 21.03.2019).

8. Вирабов, И. Я убийца и злодей? Как Пастернак подписал «покаянные письма» // Российская газета : сайт. - Москва, 1998-.- Режим доступа: https://rg.ru/2013/11/03/pasternak-site.html (дата обращения: 11.03.2019).

9. Овсянико-Куликовский, Д. Н. Лев Николаевич Толстой как художник : моногр. - Москва : Либроком, 2012. $-312 \mathrm{c}$.

10. Лихачёв, Д. С. Размышления над романом Б. Л. Пастернака «Доктор Живаго» // Новый мир. - 1988. № 1. - С. 111-130.

11. Быков, Д. Борис Пастернак. - Москва: Молодая гвардия, 2016. -896 с.

12. Пастернак, Б. Доктор Живаго : роман. - Санкт-Петербург : Азбука-классика, 2009. - 544 с.

13. Система образов романа «Доктор Живаго» Б. Л. Пастернака // AllSoch : сайт. - 2002- . - URL: https://www.allsoch.ru/sochineniya/27528 (дата обращения: 16.02.2019).

14. Агафонова Д. В. Прототипы главных героев романа Л. Н. Толстого «Анна Каренина»: версии и факты (по материалам филологических исследований и мемуарно-эпистолярного наследия современников писателя) / Д. В. Агафонова, О. Ю. Колпецкая // Scientific perspectives - 2018 : сб. матер. XXXV междунар. науч.-практ. конф. (Москва, 26 марта 2018 г.). - Москва : НЦ «Олимп», 2018. - С. 12-14.

15. Антон Лубченко поставит в Баварии собственную оперу «Доктор Живаго» // ClassicalMusicNews.Ru : [новости академической музыки]. - Москва, 2006-.- URL: https://www.classicalmusicnews.ru/anons/antonlubchenko-postavit-v-bavarii-sobstvennuyu-operu-doktor-zhivago/ (дата обращения: 08.03.2019). 
Daria $V$. Kalinina

Dmitri Hvorostovsky Siberian State Institute of Arts (Krasnoyarsk, Russia)

deresel@yandex.ru

\title{
“ANNA KARENINA" BY LEON TOLSTOY AND "DOCTOR ZHIVAGO" BY BORIS PASTERNAK AS LITERATURE SOURCES FOR ANTON LUNCHENKO'S MUSICAL COMPOSITIONS
}

Исследование выполнено при поддержке Красноярского краевого фонда поддержки научной и научно-технической деятельности.

Abstract. The paper reviews historical, social and political context of appearance of masterpieces of Russian and world literature: Leon Tolstoy's novel “Anna Karenina" (1873-1877) and Boris Pasternak's novel "Doctor Zhivago" (1945-1955); these writings were taken as a basis for historical musical drama in 15 episodes "Doctor Zhivago" (op. 71; 2010) and for dramatic poem for grand orchestra "Anna Karenina" (op. 74; 2010) by Anton Lubchenko (1985), a Russian composer and conductor. The author of the article notes ideological and artistic, subject and aesthetic closeness between novels one of which was written more than 50 years later than the second. The paper says facts from writers' biographies that got artistic understanding in their literature texts, gives several cases of contemporary readers' comments about philosophical and artistic qualities of writings. Also, the author hypothesizes a reason why Anton Lubchenko chose plot constructions of Russian classic literature texts mentioned above as a basis for his composer's intention.

Keywords: Leon Tolstoy, “Anna Karenina” (a novel), Boris Pasternak, “Doctor Zhivago” (a novel), Anton Lubchenko (composer), “Anna Karenina” (dramatic poem for grand orchestra), "Doctor Zhivago” (historical musical drama in 15 episodes), real-life inspirations for fictional characters, dramaturgy, grand forms of instrumental orchestral music.

УДК $801.81: 821=512.141 “ 1900 / 1920-\mathrm{e} ”$

DOI: $10.32340 / 2414-9101-2019-4-39-46$

Н. А. Хуббитдинова, доктор филологических наук Институт истории, языка и литературы Уфимского федерального исследовательского центра Российской академии наук (Уфа, Россия) narkas08@mail.ru

\section{РЕПРЕЗЕНТАЦИЯ ФОЛЬКЛОРА КАК «КУЛЬТУРНОЙ ПАМЯТИ» В БАШКИРСКОЙ ЛИТЕРАТУРЕ НАЧАЛА ХХ ВЕКА В «ДИАЛОГЕ КУЛЬТУР» ПОКОЛЕНИЙ}

\author{
Исследование выполнено при финансовой поддержке РФФИ в рамках проекта № 19-412-020008 \\ "Архаический эпос башкирского народа: художественно-стилистический аспект \\ (эпосы “Урал-батыр”, “Акбузат”, “Заятуляк и Хыухылу”)»
}

Аннотация. Изложены результаты анализа характерных особенностей развития башкирской художественной литературы первой четверти XX в., активно воспринявшей влияние национального башкирского и - шире - тюркского фольклора. Представлен обзор комплекса факторов, обусловивших рост интереса башкирских литераторов к персоносфере, сюжетным конструкциям и образам эпических и лиро-эпических жанров народной башкирской поэзии и прозы (сказаний, преданий, легенд, баитов, песен и пр.) в условиях революции и гражданской войны. В контексте рассматриваемой темы автор характеризует феномен диалога поколений одного этноса, руководствующихся несхожими мировоззренческими идеалами и оперирующих различными культурными смыслами. Отмечается, что башкирские писатели, освоившие фольклорной пласт этнического литературного творчества, становились носителями национального духовного наследия и приобретали мастерство сэсэновбашкирских певцов-импровизаторов; их произведения заучивались наизусть потомками, переходили в устную форму бытования.

${ }^{1}$ Начало. Окончание: «Учёные записки (Алтайская государственная академия культуры и искусств)». 2019. № 4. Загл.: Репрезентация фольклора как «культурной памяти» в башкирской литературе начала ХХ века в «диалоге культур» поколений. 